\title{
Salvage felling in the Czech Republic's forests during the last twenty years
}

\author{
Petr Zahradník*, Marie Zahradníková \\ Forestry and Game Management Research Institute, Strnady 136, CZ - 25202 Jiloviště, Czech Republic
}

\begin{abstract}
The incidence of salvage felling is a significant indicator of stands ${ }^{`}$ health and stability. Health is mainly indicated by biotic and anthropogenic factors, while abiotic effects are primarily an indicator of a stand's stability. All these factors influence each other and subsequently they can result in salvage felling. For the Czech Republic, there have been relevant data for the period since 1964 . Actually, recent data cover approximately $70 \%$ of the Czech Republic's area in the twenty-year period assessed in this text. During this period, the volume of salvage felling amounted to 89.2 million $\mathrm{m}^{3}$ which represents $28.4 \%$ of total felling in this period. The largest share is caused by abiotic effects (18.6\%), next by biotic agents $(9.6 \%)$ and anthropogenic are only responsible for $0.2 \%$. In the last two years, the volume of salvage felling caused by biotic agents was higher than the volume of salvage felling caused by abiotic and anthropogenic agents for the first time. In terms of biotic agents, almost the whole volume is represented by bark beetle wood as a result of spruce stands infestation by the European spruce bark beetle - Ips typographus (L.) and double-spined bark beetle - Ips duplicatus (Sahl.), and to a small extent also by other species of bark beetles on spruce, pine and occasionally other wood tree species. In the last three years, mainly the incidence of the Ips typographus L., has concentrated in North Moravia and Silesia. Currently, it is also spreading in South Moravia and Bohemia and in districts along the state borders with Austria and Germany, with the most serious situation in this region being the one in the Bohemian-Moravian Highlands.
\end{abstract}

Key words: salvage felling; harmful agents; windstorms; bark beetles; drought; Ips typographus

Editor: Karolina Lukášová

\section{Introduction}

Forests in the Czech Republic cover approximately one third of the territory (2,670 thousand ha in total). In the last three centuries, there have been considerable changes in terms of the area, age as well as species structure. Mixed and broadleaved stands were replaced by spruce and - less frequently - pine monocultures, often even-aged. The spruce currently accounts for $50.5 \%$ of stands, and pine for $16.4 \%$ respectively. This has led to decreased stand stability in respect to damage caused by abiotic agents (wind, snow, glaze, drought) and recently also by anthropogenic effects (air pollution). Coniferous monocultures provide favourable conditions for insect pests gradation, mainly for bark beetles, which is often responsible for salvage felling. In the monitored period, there was basically no salvage felling due to damages caused by folivorous insects. The worsening of the situation and increase in salvage felling is significantly affected by the global climate change, especially occur- rence of extreme conditions (especially windstorms, long droughts and extremely high temperatures in the vegetative period).

Extensive damages of forest stands have also been known from the past. It is not easy to evaluate their contribution to the then felling. For the time period starting at the turn of the $18^{\text {th }}$ and $19^{\text {th }}$ century, we know, at best, their extent and location (Kudela 1980). Some of these cases were rather extensive and they may have made a significant share to the overall felling. Herein, we should mention at least the windstorm disaster and subsequently a bark beetle outbreak in Šumava in the years 1868-1878 (Jelínek 1981) which extended to 7-11 million $\mathrm{m}^{3}$ depending on the source (Pfeffer 1952; Simanov 2014). Even more catastrophic was the Lymantria monacha (L.) outbreak in the years 1917-1927 (Komárek 1931) when 15-20 million $\mathrm{m}^{3}$ on the area of more than 600 thousand ha was affected (Kudela 1980; Skuhravý 2002; Simanov 2014). This also proves that also folivorous insect can significantly contribute 
to salvage felling. (However with the development of modern monitoring methods and protective measures - namely chemical interventions, often aerial ones this phenomenon has been largely eliminated and it is now only limited to sporadic cases of a small extent.) An abnormal growth of gradation of various insect species and subsequent outbreaks occurred mainly in the 1970 s and 1980s (Liška et al. 1991). Nevertheless, the factor of timely and effective interventions against folivorous insects decreased their contribution to salvage felling to a minimum. Therefore the most extensive damage was the one caused by ait pollution which affected a majority of borderline mountain forests, especially in the north from the west to the east, which led (in combination with bark beetles) to actual deforestation (except for the eastern area). Currently, the consequence of this disaster can be seen mostly indirectly (soil acidification, insufficient nutrition) and the actual damage caused by air pollution is rather marginal. In the long run, salvage felling in the last forty years was mainly caused by abiotic agents especially wind) and bark beetles (on spruces, the most important is European spruce bark beetle).

\section{Methods and data collection}

The methods of systematic data collection were elaborated in the late 1950s, but in was never used in the originally prepared form, only in the slightly adjusted one (Šrot 1962, 1964, 1965; Mentberger 1964). In 1959, a unified countrywide control, register and prognosis protection service was established based on the agreement of the Forestry Administration of the Ministry of Agriculture, Forestry and Water Management with the Forestry and Game Management Research Institute in Strnady (together with the Forestry Research Institute in Banská Štiavnica). L 116 reports (incidence of harmful agents in general) and L 117 reports (incidence of outbreak pests) were introduced. For their filling and sending, Directives for Reporting Occurrence of Forest Harmful Agents, and for Control and Prognosis of Outbreak Pests were adopted on $8^{\text {th }}$ November 1963 and became effective as of $1^{\text {st }}$ January 1964 . In practice, only L 116 reports covering all basic harmful agents, both abiotic and biotic, were used. Data of L 116 reports in Czechia have been available at the Forestry and Game Management Research Institute since 1964. In the course of time, there have been changes in the range of reported events, some of the categories vanished. Major changes came about in the 1990s. There were three reasons. Firstly, it was the transformation of forestry, including the privatization. Gradually, up to $40 \%$ forests were given back to municipalities and citizens (currently, after the completion of privatization and recovery of forests to churches, the figure reached approximately
$50 \%)$. As a result, we have only had available data from approximately $70-75 \%$ of the whole area of Czech forests (the figures fluctuates over years) since 1992. Secondly, the Forest Protection Service was founded in 1995. It modified previously used reports about harmful agents. Thirdly, another change occurred in 1998 when reporting and registers were introduced based on districts instead of forest estates.

Actual data come, to a certain extent, from three sources. The data of overall felling comes from the Report on the State of Forests and Forestry in the Czech Republic in the respective years (1998-2016) which uses data provided by the Czech Statistical Office. The information on the overall felling in 2017 was provided by the Czech Statistical Office before the official publication, so it may slightly vary from the final official figure. The most problematic information is the volume of salvage felling. There are three possible sources where to obtain them. Firstly, it is the above mentioned Czech Statistical Office which recognizes four categories of salvage felling based on its cause - natural disasters, emissions, insects and others. Secondly, salvage felling is also reported in the above mentioned Report on the State of Forests and Forestry in the Czech Republic for the given year. These figures may vary, however, and sometimes they do significantly (see Table 1). Thirdly, data can also be found in the register based on reports send by forest owners which get processed by the Forest Protection Service. This source fully covers state-owned forests (state-owned enterprises "Lesy České republiky, s. p." and "Vojenské lesy a statky, s. p."; forests in national parks: the Krkonoše National Park, Šumava National Park, Podyjí National Park and České Švýcarsko National Park; forests owned by universities: Czech University of Life Sciences in Prague and Mendel University in Brno; and Forests of the President's Office in Lány) as well as a part of private and municipal forests (mostly larger forest properties). In total, approximately $70 \%$ of the whole forest area is covered. Variability in the data from different sources is probably caused by different methodological approaches. While the Czech Statistical Office collects the data directly from respondents, the data in the Report on the State of Forests and Forestry in the Czech Republic are based on the register of the Forest Protection Service and their calculations are completed by estimation for the rest of the Czech territory. This evaluation used the data as reported by forest owners and categorized based on individual districts, but not recalculated for the rest of the territory. We are convinced this is methodologically the most appropriate approach, as the re-calculation based on estimates does not take into consideration the structure of tree species, age structure etc. and as it is done mechanically, to a certain extent, it can result in inaccuracy. The volume suggested by the Czech Statistical Office's data is considerably higher and we do not consider it to be completely accurate. 
Table 1. Volume of salvage felling according to data from different sources (CSO - Czech Statistical Office; MA - Ministry of Agriculture; FPS - Forest Protection Service).

\begin{tabular}{lccc}
\hline & \multicolumn{3}{c}{ Volume of salvage felling } \\
\cline { 2 - 4 } Years & CSO & MA & FPS \\
\cline { 2 - 4 } & & 2.68 & \\
\hline 1998 & - & 2.62 & 2.68 \\
1999 & - & 2.29 & 2.62 \\
2000 & 3.29 & 1.55 & 2.59 \\
2001 & 2.37 & 2.96 & 1.55 \\
2002 & 4.21 & 7.87 & 2.96 \\
2003 & 8.19 & 5.15 & 4.95 \\
2004 & 5.38 & 3.85 & 3.61 \\
2005 & 4.54 & 7.37 & 2.88 \\
2006 & 8.03 & 15.48 & 6.71 \\
2007 & 14.89 & 10.13 & 10.84 \\
2008 & 10.75 & 6.13 & 7.10 \\
2009 & 6.63 & 6.09 & 5.71 \\
2010 & 6.46 & 3.83 & 4.24 \\
2011 & 3.82 & 3.25 & 2.57 \\
2012 & 3.24 & 4.17 & 3.67 \\
2013 & 4.25 & 4.38 & 2.84 \\
2014 & 4.53 & 6.89 & 3.01 \\
2015 & 8.15 & 4.96 & 5.17 \\
2016 & 9.40 & - & 6.07 \\
2017 & - & & 7.44 \\
\hline
\end{tabular}

Abiotic agents include the following factors: damage caused by wind, snow, icing and glazed frost, drought and other factors. Other factors can be defined as a cause of salvage felling which could not be specified or a significant combination of several factors when categorization under one of them might skew the resulting data.

Anthropogenic agents only include damage by air pollution. Fire damage is not included, as their significance and extent in respect to salvage felling is usually marginal in the Czech Republic; furthermore it would be complicated to distinguish between cases with an abiotic and anthropogenic cause. Another omission relates to spruce yellowing which gets reported to the Forest Protection Service, but its categorization is not unambiguous and furthermore, the extent is not very significant.

Biotic agents only include several harmful agents. The most significant cause is the incidence of bark beetle on spruces (dominantly, Ips typographus (L.), partly also Ips duplicatus (Sahl.) and Pityogenes chalcographus (L.). Bark beetles on pines include Ips acuminatus (Gyll.), Tomicus minor (Hart.) and Phaenops cyanea (F.). Bark beetles on other tree species do not affect the volume of salvage felling given the actual extent. Folivorous insects did not contribute to occurrence of salvage felling in the monitored time period. As for fungal pathogens, wood decaying fungi are represented by Armillaria ostoyae (Romagn.) Herink. Other important species of wood decaying fungi such as Stereum sanguinolentum (Alb. Et Schwein.) Fr., Heterobasidion parviporum Niemelä et Korhonen and H. annosum (Fr.) Bref. are not mentioned as they have not been monitored.

The data were analysed in the STATISTICA 12 program using basic statistics. As the data do not have normal distribution, Kruskal-Wallis ANOVA at $5 \%$ level of the significance $(\mathrm{p}<0.05)$ was used. Results are followed by the post hoc test.

\section{Results}

\subsection{Salvage felling}

According to the National Forest Inventarization, the current overall wood resources are estimated to be approximately 942.2 million $\mathrm{m}^{3}$, with the overall spruce resources (which is the most frequent subject to salvage felling) equalling 510.7 million $^{3}$ (Anonymous 2017a). The total felling in Czech forests reached 314.43 million $\mathrm{m}^{3}$, i.e. $33.37 \%$ of the total resources in 1998-2017. In ratio to the average total felling, its volume fluctuated between $89.06-117.74 \%$. Salvage felling reached 89.18 million $\mathrm{m}^{3}$, i.e. $28.36 \%$ of the total felling in 1998-2017. In this period, the salvage felling figures fluctuated in the range of $34.75-243.05 \%$ in relation to the average salvage felling.

Table 2. Volume of total felling and salvage felling in the Czech Republic within the period 1998-2017.

\begin{tabular}{lcccccc}
\hline \multirow{2}{*}{ Kind of felling } & Sum & $\begin{array}{c}\text { Annual } \\
\text { average }\end{array}$ & $\begin{array}{c}\text { Standard } \\
\text { deviation }\end{array}$ & $\begin{array}{c}\text { Maxi- } \\
\text { mum }\end{array}$ & $\begin{array}{c}\text { Mini- } \\
\text { mum }\end{array}$ & $\begin{array}{c}\text { Number } \\
\text { of years }\end{array}$ \\
\cline { 2 - 7 } & \multicolumn{6}{c}{ mil. m $^{3}$} \\
\hline Total felling & 314.43 & 15.72 & 1.25 & 18.51 & 14.00 & 20 \\
Salvage felling & 89.18 & 4.46 & 2.29 & 10.84 & 1.55 & 20 \\
\hline
\end{tabular}

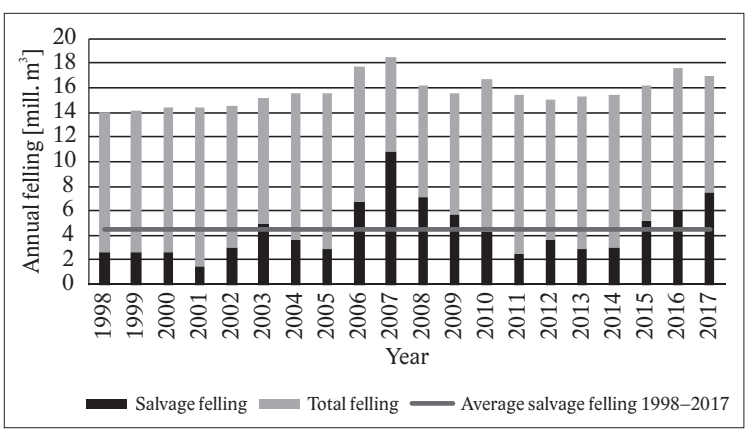

Fig. 1. Development of both total and salvage felling in the Czech Republic over the period 1998-2017.

\subsection{Harmful agents}

Salvage felling is caused by three groups of harmful agents. Abiotic and biotic agents are the leading ones, and they largely contribute to salvage felling. Anthropogenic agents are currently of a very little importance (although they ranked among the most important ones in the 1970s and 1980s). In the last twenty years, the share of these groups on the volume of salvage felling was as follows: abiotic agents $-65.49 \%$, biotic agents $-33.77 \%$ and anthropogenic agents $-0.74 \%$.

The results of the Kruskal-Wallis ANOVA proved a statistically significant difference between the amount of damage caused by abiotic, biotic and anthropogenic harmful agents $(p=0.0000)$. The Post hoc test (Multiple comparisons $p$ value) revealed statistically significant differences between anthropogenic and biotic $(p=0.0000)$ and abiotic $(p=0.0000)$ harmful agents. No statistically significant difference was proved between biotic and abiotic harmful agents $(\mathrm{p}=0.1170)$. 
Using Kruskal-Wallis ANOVA as well as the Median test showed that the major causal agent of forest damages are abiotic harmful agents compared to the minor cause - anthropogenic harmful agents.

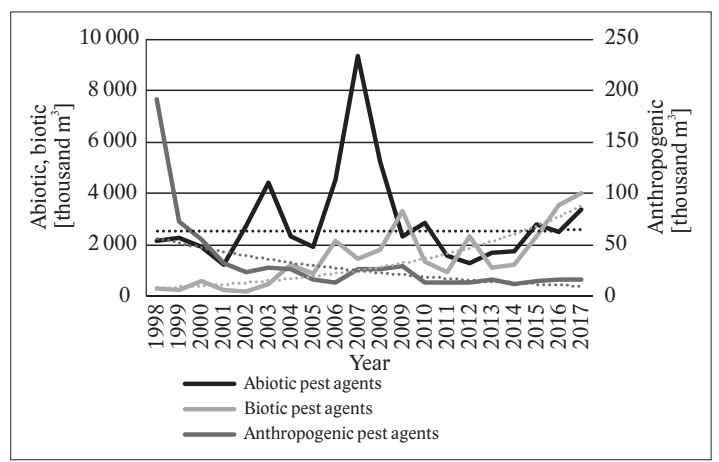

Fig. 2. Development of volume of processed wood from salvage felling cased by the three major groups of harmful agents.

The results of the a Kruskal-Wallis ANOVA proved a statistically significant difference between the amount of damage caused by abiotic harmful agents (wind, snow, icing + glaze, drought, other abiotic harmful agents) $(p=0.0000)$. The Post hoc test (Multiple comparisons $p$ value) revealed the following: a statistically significant difference was proved between wind and snow $(p=0.0003)$, wind and icing + glaze $(p=0.0000)$, wind and other abiotic harmful agents $(p=0.0000)$, snow and other abiotic harmful agents $(p=0.0179)$, drought and icing + glaze $(p=0.0001)$, drought and other abiotic harmful agents $(p=0.0000)$. A statistically significant difference was not proved between wind and drought (0.1067), snow and icing + glaze $(p=0.0617)$, snow and drought $(\mathrm{p}=0.9811)$, icing + glaze and other abiotic agents $(p=1.0000)$.

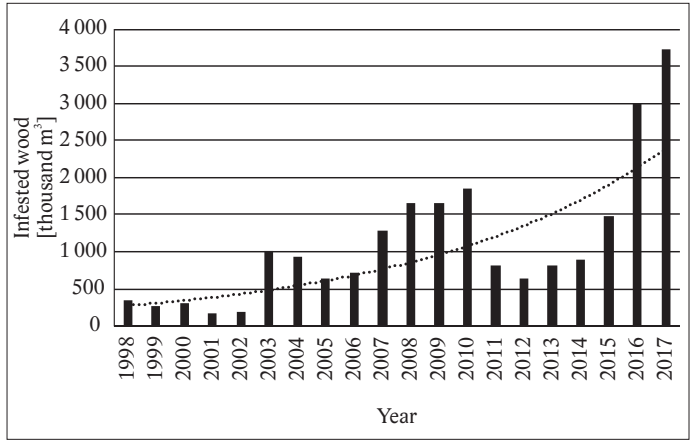

Fig. 3. Recorded volume of spruce wood infested by bark beetles in the Czech Republic within the period 1998-2017.

Table 6. The selected major harmful agents in the Czech Republic forests within the period 1998-2017.

\begin{tabular}{lcc}
\hline \multirow{2}{*}{ Harmful agents } & \multicolumn{2}{c}{ Total volume of processed wood from salvage felling } \\
\cline { 2 - 3 } & {$\left[\mathrm{mil}^{3} \mathrm{~m}^{3}\right]$} & {$[\%]$} \\
\hline Wind & 43.757 & 65.78 \\
Bark beetles on spruce & 22.102 & 33.23 \\
Air pollution & 0.62 & 1 \\
Total & 66.521 & 100 \\
\hline
\end{tabular}

Among one-off factors, windstorms cause the most serious damage. One of the strongest ones in the history was the Kyrill windstorm in 2007 (according to the Forest Protection Service, its effect resulted in almost 9 million $\mathrm{m}^{3}$ damage, but the report did not cover the whole territory of the Czech Republic). Only damage caused by the Vivian and Wiebke windstorms in 1990 is comparable with the consequence of the Kyrill windstorm. In 1976, 1984, 1985 and 1986, damage due to windstorm reached approximately 5-6 million $\mathrm{m}^{3}$. Usually, it is around $1 \mathrm{mil}$ lion $\mathrm{m}^{3}$, but there are several more years when the range of $2-4$ million $\mathrm{m}^{3}$ was reported (this related to the monitored period starting from 1964).

Table 3. Volume of processed wood by major groups of harmful agents in the Czech Republic forests within the period 19982017.

\begin{tabular}{lcccc}
\hline \multirow{2}{*}{ Major groups of harmful agents } & Sum & Median & Standard deviation & Minimum \\
\cline { 2 - 5 } & & & {$\left[\mathrm{mil}^{3}\right]$} & \\
\hline Abiotic Harmful agents & 58.406 & 2.343 & 1.853 & 1.238 \\
Biotic Harmful agents & 30.116 & 1.241 & 1.142 & 9.316 \\
Anthropogenic Harmful agents & 0.662 & 0.021 & 0.040 & 0.203 \\
Total & 89.184 & 1.233 & 1.714 & 0.012 \\
\hline
\end{tabular}

Table 4. Volume of processed wood from salvage felling due to selected abiotic and anthropogenic harmful agents in the Czech Republic forests within the period 1998-2017.

\begin{tabular}{|c|c|c|c|c|c|}
\hline \multirow{2}{*}{ Major group of harmful agents } & Sum & Median & Standard deviation & Minimum & Maximum \\
\hline & \multicolumn{4}{|c|}{$\left[\mathrm{mil} . \mathrm{m}^{3}\right]$} & \\
\hline$\overline{\text { Wind }}$ & 43.757 & 1.580 & 1.844 & 0.953 & 8.842 \\
\hline Snow & 5.414 & 0.117 & 0.561 & 0.042 & 2.590 \\
\hline Icing + Glaze & 1.273 & 0.043 & 0.083 & 0.011 & 0.362 \\
\hline Other abiotic harmful agents & 0.893 & 0.035 & 0.029 & 14.00 & 0.110 \\
\hline
\end{tabular}

Table 5. Volume of processed wood from salvage felling due to selected biotic harmful agents in the Czech Republic forests within the period 1998-2017.

\begin{tabular}{lcccc}
\hline \multirow{2}{*}{ Major group of pests /pathogens } & Sum & Median & Standard deviation & Minimum \\
\cline { 2 - 5 } & & & {$\left[\mathrm{mil}^{3} \mathrm{~m}^{3}\right]$} & \\
\hline Bark beetles on spruce & 22.102 & 0.856 & 0.919 & 179.00 \\
Bark beetles on pine & 0.140 & 0.005 & 0.005 & 3.727 \\
Armillaria spp. & 3.830 & 0.186 & 0.137 & 0.002 \\
\hline
\end{tabular}




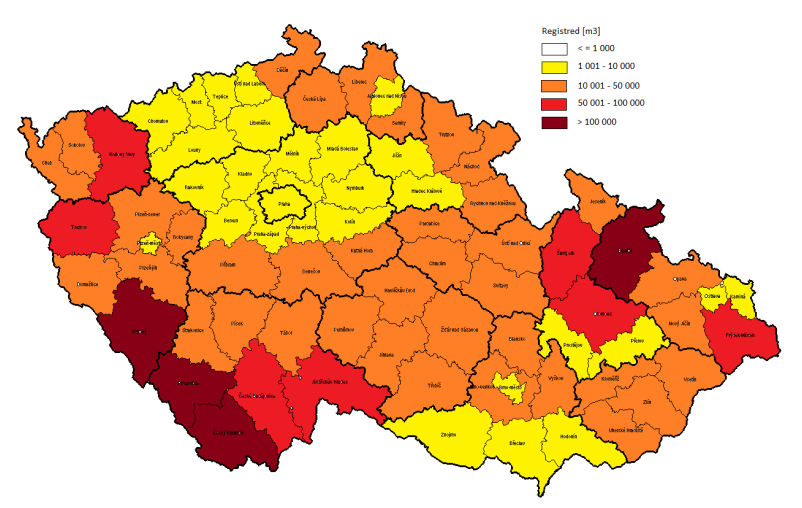

Fig. 4. Distribution of wood volume processed in the salvage felling caused by wind (average from years 1998-2017).

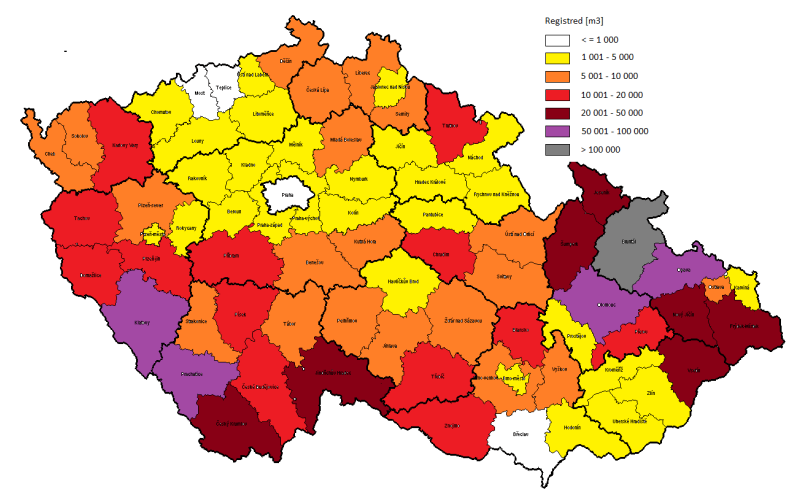

Fig. 5. Distribution of wood volume processed in the salvage felling caused by spruce bark beetles (average from years 1998-2017).

Looking at the period of 1998-2017, snow proved to be an intensive harmful agent in 2006 when the volume of damaged stands reached 2.6 million $\mathrm{m}^{3}$. Large damage was seen only in the years 1979 and 1980 ( 3.1 million $\mathrm{m}^{3}$, a3.2 million $\mathrm{m}^{3}$ respectively). In theyears 1967,1970 and 1981, the level of 1.5 million $\mathrm{m}^{3}$ damage was exceeded, and in 1968 and 1982 the volume of damage was 1 million $\mathrm{m}^{3}$. In other monitored years, it fluctuated under the level of 500 thousand $\mathrm{m}^{3}$ or around it.

Drought is a typical phenomenon of the recent years, but its negative consequences were also obvious in the past. During the period of harmful agents monitoring (since 1964), such effects were observed in 1993-1995, when the total of 4.2 million $\mathrm{m}^{3}$ of damaged wood was reported. Usually, the volume of stands damaged by drought reaches the maximum of approximately 0.2 million $\mathrm{m}^{3}$, but in some years, the range increases to 0.3 0.6 mil, $\mathrm{m}^{3}$, specifically in the second half of the $1970 \mathrm{~s}$, in the mid 1980s and in the middle of the first decade of the $3^{\text {rd }}$ millennium.

Damage due to air pollution culminated in the late 1970s and significantly dropped in the early 1990s. At that time, annual volumes of recorded damaged wood exceeded 0.5 million $\mathrm{m}^{3}$, while in 1980 and 1981, they even exceeded 1 million $\mathrm{m}^{3}$. In the period of 1998-2017 covered in this study, they only amounted to approxi- mately tens of thousands of $\mathrm{m}^{3}$ and the significance of this type of damage was thus rather marginal (Zahradník et al 2018).

Ips typographus is the most important biotic harmful agent. Its gradation has lasted since 2003 with minor variations. Since 2015, the volume of recorded bark beetle wood has continued to grow and it has reached its record level. Since 1964 there have been two more rather significant gradations - in the years 1983-1988 (volume of 6.65 mil. $\mathrm{m}^{3}$ ) and 1993-1996 (volume $6.75 \mathrm{mil}^{3} \mathrm{~m}^{3}$ ) (Liška et al. 1991; Zahradník 1997, 2008).

Table 7. Summary of major disturbance in the Czech Republic from 1998 to 2017.

\begin{tabular}{lcc}
\hline Type of disturbance & Occurrence date & $\begin{array}{c}\text { Volume } \\
{\left[\mathrm{mil}^{3} \mathrm{~m}^{3}\right.}\end{array}$ \\
\hline Windstorm „Lothar“ & 26-27 December 1999 & 2.0 \\
Snowfall „Tamara“ & January 2006 & 2.6 \\
Windstorm „Kyrill“ & 9 January 2007 & $10-12$ \\
Windstorm „Emma“ & 1-5 March 2008 & 3 \\
Windstorm „Niklas“ & 28-29 June 2015 & 0.5 \\
Windstorm „Herwart“ & 29 October 2017 & 3 \\
Ips typographus & 2003-2004 & 1.9 \\
Ips typographus & 2007-2010 & 6.5 \\
Ips typographus & 2015-2017 & 8.2 \\
Ips typographus & 2003-2017 & 21.1 \\
Drought episodes & 2015-2017 & 3.1 \\
\hline
\end{tabular}

\section{Discussion}

The volume of salvage felling caused by various harmful agents is a significant indicator of forest stands' health and stability (Anonymous 2017a; Knížek et al. 2017; Kunca et al. 2019). The most important indicator is the total volume of salvage felling which is an objective piece of information on forced felling due to harmful agents, because the volume of total felling (or, to be more specific, intentional felling), depends on numerous factors including timber sales, planned volumes of felling etc. and it can fluctuate considerably. There are three categories of agents affecting salvage felling - abiotic, anthropogenic and biotic (Schelhaas et al. 2003; Spiecker 2003). In the Czech Republic, the total of 30 harmful agents are monitored currently - with 5 of them being abiotic factors, 2 anthropogenic (as classification of spruce yellowing among anthropogenic agents is questionable) and 23 biotic agents (or agent groups) and additionally some other types, depending on what is relevant in the given year (Knížek et al. 2017). Monitored harmful species change over time - in 1962, there were only 17 types of outbreak pests. This also varies in neighbouring countries. For example, the monitoring in Slovakia covers 53 harmful agents (Kunca 2017) and in Poland as many as 109 (Anonymous 2017b).

In the Czech Republic, as seen in the long run, the most important factor contributing to salvage felling can be seen in abiotic effects, mainly wind (Zahradník et al. 2018). However, windbreaks do not afflict the Czech Republic only, but other Central European countries as well (Simanov 2014; Kunca \& Zúbrik 2006; Trębski, 
2017). These disasters can largely affect the volume of salvage felling and its share in the total felling, as they can amount to millions of $\mathrm{m}^{3}$, even exceeding 10 million $\mathrm{m}^{3}$ in individual countries. They occur randomly and in a various extent across Central Europe.

Out of biotic harmful agents in the post-war history, bark beetle on the spruce is considered to be the most important one, namely Ips typographus, and in Moravia and Silesia also Ips duplicatus (Skuhravý 2002; Knížek et al. 2017). Other species of bark beetles often accompany the previous two and their incidence is often reported together with Ips typographus - this applies to Pityogenes chalcographus and Ips amitinus. The situation is similar in the neighbouring countries (Liška 2018). Only in Poland, there is also an important role of folivorous insects, mainly in pine stands where it has outbreaks in large areas, but due to insecticide application, this only contributes to salvage felling marginally (Anonymous 2017b).

In the Czech Republic in the last twoyears - 2016 and 2017 - the volume of salvage felling due to biotic agent exceeded for the first time the volume of salvage felling caused by abiotic agents (Knížek et al. 2017; Knížek \& Liška 2018); anthropogenic agents only played a marginal role in the monitored period (Knížek \& Liška 2018). Air pollution, as the major part of anthropogenic damage, became significant in the 1970s and 1980s and not only in Czechoslovakia, but also in Germany (the former German Democratic Republic) and Poland.

In the monitored period, the percentage of salvage felling on the total felling in the Czech Republic has fluctuated in the range of $35-143 \%$, and the average was $139 \%$. In Slovakia, this share in the years of 2004-2013 ranged from 38.8 to $65.9 \%$, and the average was $53.2 \%$ (Kunca et al. 2015).

Windstorms have caused more frequent and extensive damage in the Czech Republic in the past twenty to thirty years, yet this also applies to the rest of Europe. The Vivian windstorm of 1990 damaged 120 million $\mathrm{m}^{3}$ wood in Western Europe (König et al. 1995). Another important windstorm was Lothar in 1999 together with Anatol and Martin which damaged approximately 180 million $\mathrm{m}^{3}$ in Western Europe (Sacre 2002). At the turn of August and September 2005, Denmark, Estonia and South of Sweden were afflicted by the Gudrun windstorm which damaged 75 million $\mathrm{m}^{3}$ of wood in Southern Sweden only (Schlyter et al. 2006; Langström et al. 2009). These windstorms did not affect the Czech Republic though. The Kyrill windstorm of January 2007 afflicted a large part of Europe (from the United Kingdom and France to Belarus, Ukraine and Slovenia) and damaged 55 million $\mathrm{m}^{3}$ of wood. This windstorm also damaged stands in the Czech Republic. Unlike the previous above mentioned windstorms which did not hit our territory, this one had a serious impact here and caused damage of 10-12 million $\mathrm{m}^{3}$. At the beginning of March 2008, the Czech Republic was struck by the Emma windstorm which damaged approximately 3 million $\mathrm{m}^{3}$ (Simanov 2014). The latter two windstorms affected the volume of salvage felling in the respective years and they also marked the beginning of the subsequent bark beetle outbreak which had a further effect on the salvage felling volume (Knížek et al. 2017). The most recent important windstorm resulting in extensive damage was Herwart in October 2017 which damaged approximately 2.5 million $\mathrm{m}^{3}$ in the Czech Republic (Lubojacký \& Knížek 2017). There were many other windstorms with a bigger or lesser effect on the volume of salvage felling. Local windstorms (sometimes of a large extent) were also Alžběta which hit the High Tatra Mountains in Slovakia in the extent of more than 5 million $\mathrm{m}^{3}$ (Koreň 2005; Kunca 2005; Kunca \& Zúbrik 2006) and the groups of windstorm of 11.-12. August 2017 in Poland which caused damage of approximately 10 million $\mathrm{m}^{3}$ and major windbreaks (Trębski 2017).

Significant elements influencing the level of damage by wind are not only the wind force, but also its direction, the tree species and the age of the stand. These factors were studied in the Czech Republic by Vicena (1964) as well as Vicena et al. (1979). The predominant directions of wind in Slovakia were explored by Konôpka et al. (2008) who pointed out considerable regional differences in the, direction of predominant wind. On the European level, this topic was covered similarly by Gardiner et al. (2008, 2011).

Schelhaas et al. (2003) stated that windbreaks constitute up to $53 \%$ of forest stands disturbance in Europe. In the Czech Republic, it was $49 \%$ in the monitored period. As the frequency of windstorms has been rising recently, and similarly forest damage caused by these windstorms has been increasing as well, this comparison does not seem completely appropriate.

Although wind has been the crucial abiotic factor contributing to salvage felling in the long run, there are also time periods when other factors can manifest themselves rather significantly. In 2006, the volume of snowbreaks exceeded 2.5 million $\mathrm{m}^{3}$, while wind only accounted for less than 0.5 million $\mathrm{m}^{3}$ in the same year. Even abiotic agents, often seen as generally less significant, can unexpectedly result in large damage and exceed the effect of windbreaks. An example is the case of icing in 1996 (which is not included in the monitored period) when the related damage reached 2 million $\mathrm{m}^{3}$ (Novotný 2017). Another highly important harmful agent is among biotic agents - it is the Ips typographus (L.). Its outbreak usually follows windbreaks, and sometimes it is linked with the stands' damage by draught (Christiansen \& Bakke 1988; Pfeffer \& Skuhravý 1995; Blennow \& Olofson 2008; Grodzki 2010; Marini et al. 2013; Mezei et al. 2014; Sproul et al. 2015).

Belated treatment of breaks is unambiguously linked with one of the most serious Ips typographus outbreaks in Šumava (Jelínek 1988; Skuhravý 2002). Similarly, breaks are also mentioned as the cause of Ips typographus 
outbreaks in other countries, for example in Sweden in 1969 (Nilsson et al. 2004) as well as in 2005 and 2007 Langström et al. 2009), in Lithuania (Zolubas \& Dagilius 2009) and Siberia (Soukhovolsky 2009; Tarasova 2009). The situation was similar also in Slovakia after the Alžběta windstorm in 2004 (Koreň 2005; Kunca 2005; Kunca \& Zúbrik 2006).

Drought as a predisposition factor for the bark beetle development was mentioned by Hendrych (1930) and Kalandra \& Kolubajiv (1949). The bark beetle outbreaks of 1983-1988 and 1993-1996 are associated with abnormal drought as well (Zahradník 1997; Skuhravý 2002). Also the contemporary outbreak which started in 2003 was triggered by the extraordinarily dry and hot year of 2003, and it escalated after similar weather conditions in 2015 (Knížek et al. 2016). The bark beetle outbreak in Germany in the years 1938-1941 was caused by abnormal drought combined with high temperatures (Hodapp 1954). Similarly, the extensive outbreak in Southern Norway and Central Sweden after a windstorm in 1969 was linked with the fact that spruces were weakened by drought (Butovitsch 1971). Drought as a stressor possibly leading to subsequent bark beetle infestation was also pointed out by Maslov (2001) who wrote that the flow rate on the River Nemen was only $14 \%$ after precipitation reached only $40 \%$ of the standard rate and this situation was followed by bark beetle outbreak.

\section{Conclusions}

Wind has been the most important harmful agent in the last twenty years. We are currently witnessing the largest outbreak of Ips typographus and associated species, especially Ips duplicatus . It started in 2003 and has lasted up to present days, with minor oscillations. Progression of this outbreak escalated in 2015 after an abnormally dry and hot year, and it has continued to grow. In the years 2016 and 2017, it kept rising permanently, and in 2017 it reached the historical peak in the volume of recorded bark beetle wood. In the above-mentioned two years, it was also the first moment in history, when the volume of salvage felling caused by biotic agents exceeded the salvage felling caused by abiotic agents. The situation in spruce stands of an older age (above 60) is critical in many locations, regardless of the altitude. The most affected region is North Moravia and Silesia, where clearings as large as tens of hectares emerge after the bark beetle infestation and merge gradually. The situation is similarly bad in neighbouring countries, too - in Slovakia, in spruce areas of Poland, in Austria and Germany, especially in Bavaria (Liška 2018). There is nothing consoling about this fact, though. It is a serious phenomenon which gets multiplied by frequent and extensive breakages and mainly by a long-term precipitation deficit which decreases stand vitality, and also by high temperatures in the vegetation period which accel- erate the bark beetle growth and increase the number of generations per year. The bark beetle outbreak thus significantly affects the volume of salvage felling, more than ever in the past.

\section{Acknowledgements}

The paper was supported by the Ministry of Agriculture of the Czech Republic, institutional support MZE-RO0118.

\section{References}

Anonymous, 2017a: Zpráva o stavu lesa a lesního hospodářství České republiky v roce 2016. Praha: Ministerstvo zemědělství, 128 p.

Anonymous, 2017b: Krótkoterminowa prognóza występowania ważniejszych szkodników i chorob infekcyjnych drzew leśnych w Polsce w 2017 roku. Sękocin Stary: Institut Badawczy Leśnictwa, 194 p.

Blennow, K., Olofsson, E., 2008: The probability of wind damage in forestry under a changed wind climate. Climatic Change, 87:347-360.

Butovitsch, V., von, 1971: Undersokningar over skandeinsekternes upptradante i de stormharjade skogama i mellestra Norrlands kustland aren 1967 - 1969. Institutionen för Skogszooli, Rapporter oc Uppsatser, No. 8: 204 p.

Christiansen, E., Bakke, A., 1988: In: Berryman, A. A. (ed.): Dynamics of Forest Insect Populations. Patterns, Causes, Impications. New York, London: Plenum Press, p. 479-503.

Gardiner, B., Blennow, K., Carnus, J.-M., Fleischer, P., Ingemarson, F., Landmann, G. et al., 2011: Destructive Storms in European Forests: Past and Forthcoming Impacts. Final report to European Commision - DG Environment, European Forest Institute, Atlantic European Office - EFIATLANTIC, 138 p.

Gardiner, B., Byrne, K., Hale, S., Kamimura, K., Mitchel, S. J., Peltola, H. et al., 2008: Areview of mechanistic modeling of wind damage risk to forests. Forestry, 81:447-463.

Grodzki, W., 2010: The decline of Norway spruce Picea abies [L.] Karst. Stands in Beskid Slaski and Żiviecki: theoretical concept and reality. Beskydy, 3:19-26.

Hendrych, V., 1930: Zpráva o mrazových škodách ze zimy r. 1928-1929. Lesnická práce, 9:148-164.

Hodapp, W., 1954: Der Verlauf der der Fichtenborker - Kalamität i Bäden seit 1942. In: Wellenstein G. (ed.): Die grosse Borkenkäferkalamität in Südwestdeutschland 1944 - 1951. Ringingen: Forstschutz Sudwet, p. 11-93.

Jelínek, J., 1988: Větrná a kůrovcová kalamita na Šumavě z let 1868 až 1878 . Brandýs nad Labem: Lesprojekt, 38 p. + 12 maps. 
Kalandra, A., Kolubajiv, S., 1949: Kalamitní výskyt pilatky smrkové druhu Pachynematus scutellatus Htg. v Československu v r. 1949. Lesnická práce, 28:384-394.

Knížek, M., Liška, J., 2018: Výskyt lesních škodlivých činitelů v roce 2017 a jejich očekávaný stav v roce 2018. Zpravodaj ochrany lesa, Supplementum, 2018, 72 p.

Knížek, M., Liška, J., Modlinger, R., 2016: Výskyt lesních škodlivých činitelů $\mathrm{v}$ roce 2015 a jejich očekávaný stav v roce 2016. Zpravodaj ochrany lesa, Supplementum, $66 \mathrm{p}$.

Knížek, M., Liška, J., Modlinger, R., 2017: Výskyt lesních škodlivých činitelů $\mathrm{v}$ roce 2016 a jejich očekávaný stav v roce 2017. Zpravodaj ochrany lesa, Supplementum, 68 p.

Komárek, J., 1931: Mnišková kalamita v létech 19171927. Sborník Výzkumných ústavů zemědělských ČSR, 78:1-256 + 3 maps.

Konôpka, J., Konôpka, B., Raši, R., Nikolov, Ch., 2008: Nebezpečné smery vetra na Slovensku. Lesnícke štúdie 60, 81 p.

König, A., Mösmer, R., Bäumler, A., 1995: Silvicultural documentation of the planar storm damages in winter 1990 in Bavaria and meteorological condition at the time damage. LWF Berichte aus der Bayerischen Landesanstalt für Wald und Forstwirtschaft, 2:352.

Koreň, M., 2005: Vetrová kalamita 19. novembra 2004 - nové pohlady a konsequence. Tatry, p. 7-29.

Kudela, M., 1980: Vliv kalamit na stav lesů minulosti. Památky a př́roda, 5:228-233.

Kunca, A. (ed.), 2005: Výskyt škodlivých činitelov v lesoch Slovensko za rok 2004 a ich prognóza na rok 2005. Zvolen, Lesnícky výskumný ústav, 92 p.

Kunca, A., 2017: Výskyt škodlivých činitel'ov v lesoch Slovenska za rok 2016 a ich prognóza na rok 2017. Zvolen, Národné lesnícke centrum - Lesnícky výskumný ústav Zvolen, 79 p.

Kunca, A., Zúbrik, M., 2006: Vetrová kalamita z 19. novembra 2004. Zvolen, Národné lesnícke centrum, $40 \mathrm{p}$.

Kunca, A., Zúbrik, M., Galko, J., Vakula, J., Leontovyč, R., Konôpka, B. et al., 2015: Salvage felling in the Slovak forests in the period 2004-2013. Forestry Journal, 61:188-195.

Kunca, A., Zúbrik, M., Galko, J., Vakula, J., Leontovyč, R. et al., 2019: Salvage felling in the Slovak Republic's forests during the lasttwenty years (19982017). Central European Forestry Journal, 65:3-11

Kunca, A., Zúbrik, M., Galko, M., Vakula, J., Leontovyč, R., Konôpka, B. et al., 2019: Salvage felling in the Slovak Republic's forests during the last twenty years (1998-2017). Cent. Eur. For. J., 65:3-11.
Langström, B., Lindelöw, Å., Schroeder, M., Björklund, N., Öhrn, P., 2009: The spruce bark beetle outbreak in Sweden following the January-storms in 2005 and 2007. In: Kunca, A. \& Zúbrik, M. (ed.): Insect $\mathrm{s}$ and Fungi in Storm Areas, Proceedings of the IUFRO Working Party 7.03,10. Zvolen, Národné lesnícke centrum - Lesnícky výskumny ústav Zvolen, p. 13-19.

Liška, J., 2018: Kůrovcová kalamita - stav v okolních státech střední Evropy. Zpravodaj ochrany lesa 21:61-63.

Liška, J., Píchová, V., Knížek, M., Hochmut, R., 1991: Přehled výskytu lesních hmyzích škůdců v českých zemích. Lesnický průvodce, 3: 37 p. + 30 figs.

Lubojacký, J., Knížek M., 2017: Nebezpečí další eskalace kalamitní kůrovcové situace. Lesnická práce, 96:62.

Maslov, A. D., 2001: Usykhanie elovych nasazhdemiy ot koroeda tipografa i integraciya zashchitnykh meropriyativ. In: Mozolovskaya, E. G. (ed.): Kompleksnye mery zashchity elnikov evropeyskoy Rossii po podavleniyu vspyshkiyu massovogo razmnozheniya koroeda - tipografa. Pushkino: Centr zashchity lesa, p. 5-17.

Marini, L., Lindelöw, Å., Jönsson, A. M., Wulf, S., Schroeder, L. M., 2013: Population dynamics of the spruce bark beetle a longterm study. Oikos, 122:1768-1776.

Mentberger, J., 1964: Kontrola kalamitních škůdců. Lesnická práce, 37:38

Mezei, P., Grodzki, W., Blaženec, M., Jakuš, R., 2013: Factors influencing the wind-bark beetles' disturbance systems in the course of an Ips typographus outbreak in the Tatra Mountains. Forest Ecology and Management, 312:67-77.

Nilsson, C., Stjernquist, I., Bärring, L., Schlyter, P., Jönsson, A. M., Samuelsson, H., 2004: Recorded storm damage in Sweden forests 1901-2000. Forest Ecology and Management, 199:165-173.

Novotný, R., 2017: Abiotické vlivy a antropogenní činitelé. In: Knížek, M., Liška, J., Modlinger, R., (eds.): Výskyt lesních škodlivých činitelů $\mathrm{V}$ roce 2016 a jejich očekávaný stav v roce 2017. Zpravodaj ochrany lesa, Supplementum, p. 12-16.

Pfeffer, A., 1952: Kůrovec lýkožrout smrkový a boj proti němu. Praha, Nakladatelství Brázda, 45 p.

Pfeffer, A., Skuhravý, V., 1995: Der Buchdrucker Ips typographus L. (Col., Scolytidae) und seine Problematik in der Tsechischen Republik. Anzeiger für Schadlingskunde, Pflanzenschutz, Umweltschutz, 68:151-152.

Sacre, C., 2002: Extreme wind speed in France the '99 storms and their consequences. Journal of Wind Engineering \& Industrial Aerodynamics, 90:11631171. 
Schelhaas, M. J., Nabuurs, G. J., Schuck, A., 2003: Natural distrurbances in the European forest in the 19th and 20th centuries. Global Change Biology, 9:1620-1633.

Schlyter, F., Stjernquist, I., Bärring, L., Jönsson, A. M., Nilsson, C., 2006: Assesment of the impacts of climate change and weather extremes on boreal forests in northern Europe, focusing on Norway spruce. Climate Research, 31:75-84.

Simanov, V., 2014: Kalamity v historii a současnosti. Lesnická práce, 93:573-575.

Skuhravý, V., 2002: Lýkožrout smrkový a jeho kalamity. Praha, Agrospoj, 196 p.

Soukhovolsky, V., 2009: Insects-xylophagous in Sayana mountain forest after windthrow: population dynamics models. In: Kunca, A. \& Zúbrik, M. (eds.): Insects and Fungi in Storm Areas. Proceedings of zhe IUFRO Working Party 7.03.10. Zvolen, Národné lesnícke centrum - Lesnícky výskumny ústav Zvolen, p. 20-22.

Spiecker, H., 2003: Silvicultural management in maintaining biodiversity and resistence of forest in Europe - temperate zone. Journal of Environmental Management, 67:55-65.

Sproull, G. J., Adamus, M., Bukowski, M., Krzyzanowski, T., Szewczyk, J., Statwick, J. et al., 2015: Tree and stand-level patterns and predicators of Norway spruce mortality caused by bark beetle infestation in Tatra Mountains. Forest Ecology and Management, 354:261-272.

Šrot, M., 1962: Cíle a úkoly kontroly, evidence a prognózy škodlivých činitelů v ochraně lesů. Lesnická práce, 41:421-422.

Šrot, M., 1964: Změny v hlášení o výskytu lesních škodlivých činitelů a o kontrole kalamitních škůdců. Lesnická práce, 43:36-38.
Šrot, M., 1965: Upozornění na hlášení L 116. Lesnická práce, 45:36-37.

Tarasova, O., 2009: Regulatories of insect attack of conifer trees after windthrow in forest in Sayana mountains (middle Siberie. In: Kunca, A. \& Zúbrik, M. (eds.): Insects and Fungi in Storm Areas. Proceedings of the IUFRO Working Party 7.03.10. Zvolen, Národné lesnícke centrum - Lesnícky výskumny ústav Zvolen, p. 34-35.

Trębski, K., 2017: Největší kalamita v historii státních lesů Polska. Lesnická práce, 96:577.

Vicena, I., 1964: Ochrana proti polomům. Praha, Státní zemědělské nakladatelství, $178 \mathrm{p}$.

Vicena, I., Pařez, J., Konôpka, J., 1979: Ochrana lesů proti polomům. Praha, Státní zemědělské nakladatelství, $245 \mathrm{p}$.

Zahradník, P., 1997: Historie kůrovcových kalamit, prognózy vývoje a stanovení principů ochrany lesa proti kůrovcům. In: Kůrovcová kalamita - střet názorů. Sborník referátů celostátní konference, Písek 28.-29. 8. 1997, p. 5-9.

Zahradník, P., 2008: Kalamity v českých zemích - minulost a současnost. In: Fakta a mýty o českém lesním hospodářství. Sborník referátů ze semináře organizovaného Stálou komisí Senátu pro rozvoj venkova ve spolupráci se Sdružením vlastníků obecních a soukromých lesů v ČR a Českou zemědělskou univerzitou v Praze, Fakultou lesnickou a dřevařskou, Praha, p. 31-51.

Zahradník, P., Hellebrandová-Neudertová, K., Zahradníková, M., 2018: Přehůled výskytu lesních škodlivých činitelů v České republice od nejstarších dob po současnost. (in press)

Zolubas, P., Dagilius, R., 2009: Small scale conservation status in forests - source of bark beetle problém? In: Kunca, A. \& Zúbrik, M. (eds.): Insects and Fungi in Storm Areas. Proceedings of zhe IUFRO Working Party 7.03.10. Zvolen, Národné lesnícke centrum Lesnícky výskumny ústav Zvolen, p. 36-38. 